\title{
Aplikasi Model Rasch pada Pengembangan Skala Efikasi Diri dalam Pengambilan Keputusan Karier Siswa
}

\author{
Difa Ardiyanti ${ }^{1}$ \\ Fakultas Psikologi Universitas Ahmad Dahlan
}

\begin{abstract}
Self-efficacy has an important role in career decision making. To get an accurate student's profile of career decision making self-efficacy, required a good instrument. Unfortunately, there was only one instument of career decision-making self-efficacy and there was no improvement or current development. That instrument developed using classical test theory, an approach that had been criticized, especially about raw score and data interval. This study focused on career decision making self-efficacy scale's development using Rasch model, an approach that had more advantages compared with classical test theory. The subjects were 144 students of grade 11 in Yogyakarta. Based on the analysis results using Winsteps program, there were 20 fit items (from 36 items) with Alpha reliability coefficient was 0,91 . Overall, it can be concluded that the career decision making self-efficacy scale had been proven as a good instrument because had good psychometric properties. So in future, this instrument can be used for assessment and research.
\end{abstract}

Keywords: carrer decision making, rasch model, self-efficacy, test development

Abstrak. Efikasi diri dalam pengambilan keputusan karier berperan penting dalam pembentukan perilaku pengambilan keputusan karier siswa. Untuk mendapatkan gambaran akurat tentang efikasi diri dalam pengambilan keputusan karier siswa diperlukan alat ukur yang berkualitas. Sayangnya, baru ada satu instrumen efikasi diri dalam pengambilan keputusan karier dan belum pengembangan terkininya. Instrumen itu pun dikembangkan menggunakan pendekatan teori tes klasik, suatu pendekatan yang telah dikritik terkait skor mentah dan keintervalan data. Penelitian ini berfokus pada pengembangan skala efikasi diri dalam pengambilan keputusan karier siswa menggunakan model Rasch, suatu pendekatan yang dipandang memiliki keunggulan dibandingkan teori tes klasik. Partisipan penelitian adalah 144 siswa kelas XI SMA di Yogyakarta. Berdasarkan hasil analisis menggunakan program Winsteps, diketahui ada 20 aitem (dari 36 aitem) yang memenuhi indeks ketepatan butir-model, dengan koefisien reliabilitas alpha 0,91. Secara keseluruhan, dapat disimpulkan bahwa skala efikasi diri dalam pengambilan keputusan karier ini memiliki properti psikometris yang baik sehingga dapat digunakan untuk asesmen maupun penelitian.

Kata kunci: efikasi diri, model Rasch, pengambilan keputusan karier, pengembangan alat ukur

\footnotetext{
${ }^{1}$ Korespondensi mengenai isi artikel ini dapat dilakukan melalui: difa.ardiyanti@psy.uad.ac.id
} 
Tahapan eksplorasi karier dapat menjadi masa yang sulit bagi sejumlah remaja. Tidak semua remaja dapat mengambil keputusan dengan mudah (Creed, Patton, \& Prideaux, 2006; Argyropoulou, Sidiropoulou-Dimakakao, \& Besevegis, 2007; Hirschi \& Lage, 2007). Berdasarkan hasil survei penulis, $43 \%$ siswa kelas XI (dari 157 siswa di tiga sekolah wilayah Yogyakarta) mengalami permasalahan keyakinan diri dalam pengambilan keputusan karier. Mereka merasa belum yakin dan masih bingung dengan pilihan program studi di Perguruan Tinggi. Menurut Bandura (1997), Creed, Patton, \& Prideaux (2006), Pappas \& Kounenou (2011) serta Safaria (2016), efikasi diri merupakan indikator yang penting dalam penentuan karier individu. Efikasi diri adalah keyakinan diri individu bahwa dia mampu atau tidak mampu melakukan suatu tindakan untuk mencapai hasil tertentu dengan berhasil (Bandura, 1986). Dalam konteks permasalahan karier ini, maka merujuk pada efikasi diri dalam pengambilan keputusan karier. Flores, Ojeda, Huang, Gee, \& Lee (2006) menyebutkan bahwa efikasi diri dalam pengambilan keputusan karier adalah keyakinan individu bahwa ia mampu melakukan tugas-tugas terkait dengan membuat keputusan karier. Individu dengan efikasi diri dalam pengambilan keputusan karier yang tinggi akan berhasil membuat keputusan karier yang tepat untuk dirinya. Apabila individu sampai membuat keputusan karier dengan tidak tepat, maka akan timbul permasalahan psikologis, akademik, dan relasional (Germeijs \& Verschueren, 2006). Oleh karenanya, sangat penting mengetahui efikasi diri dalam pengambilan keputusan karier seseorang, terutama siswa SMA yang rentan mengalami kebingungan dalam menetapkan pilihan pendidikan lanjutannya. Artinya, diperlukan instrumen pengukuran efikasi diri dalam pengambilan keputusan karier yang tepat dan mampu menghasilkan data yang akurat.

Pada kenyataannya, belum banyak penelitian yang fokus pada pengembangan instrumen pengukuran efikasi diri dalam pengambilan keputusan karier. Dari hasil penelurusan, baru ditemukan satu instrumen, yakni skala efikasi diri dalam pengambilan keputusan karier yang dikembangkan oleh Taylor \& Betz (1983). Skala tersebut terdiri dari dua versi, yakni versi yang berisi 50 aitem dan versi pendek yang berisi 25 aitem. Skala versi pendek (short form) ini memiliki nilai validitas dan reliabilitas yang tinggi, sama halnya dengan skala yang berisi 50 aitem (Betz, Klein, \& Taylor, 1996; Betz \& Luzzo, 1996). Di Indonesia, pengembangan instrumen efikasi diri dalam pengambilan keputusan karier ini berupa adaptasi, yakni melakukan proses alih bahasa dari skala efikasi diri dalam pengambilan keputusan karier milik Taylor \& Betz (1983). Proses adaptasi ini dilakukan oleh Sawitri (2009), yang kemudian diteliti lebih lanjut oleh Yulianto (2012). Berbagai penelitian terkini tentang pengembangan instrumen efikasi diri dalam pengambilan karier pun lebih berfokus pada upaya mengevaluasi skala yang dikembangkan Taylor \& Betz (1983) dan adaptasinya. Di dalamnya termasuk penelitian yang menggunakan pendekatan model Rasch untuk mengevaluasi properti psikometris skala efikasi diri dalam pengambilan keputusan karier tersebut (Nam, Yang, Lee, Lee, \& Seol, 2010; Miguel, Silva, Prieto, 2013; Makransky, Rogers, Creed, 2015). Hal ini menunjukkan bahwa belum ada pembaharuan dan pengembangan yang berbeda terkait instrumen pengukuran efikasi diri dalam pengambilan keputusan karier. Oleh karenanya, 
diperlukan penelitian yang berfokus pada pengembangan dan pembaharuan terkait instrumen efikasi diri dalam pengambilan karier.

Penelitian ini berfokus pada pengembangan alat ukur efikasi diri dalam pengambilan keputusan karier menggunakan pemodelan Rasch. Dalam penelitian ini, penulis menyusun skala efikasi diri dalam pengambilan keputusan karier berdasarkan dimensi efikasi diri yang dikemukakan Bandura (1997). Dimensi tersebut adalah level (tingkat kesulitan), generality (rentang keluasan bidang), dan strength (tingkat kekuatan). Penulis memilih teori ini karena teori ini merupakan konsep dasar dari efikasi diri. Berdasarkan hasil penelusuran, teori efikasi diri dalam pengambilan keputusan karier Taylor \& Betz (1983) memang yang paling populer digunakan, namun teori ini mengandung kemiripan dengan teori perencanaan karier Jaffe \& Scott (1991) dan teori pengambilan keputusan karier Splete \& Pietrofesa (1975). Dalam teori efikasi diri dalam pengambilan keputusan karier Taylor \& Betz (1983), terdapat lima aspek dari efikasi diri dalam pengambilan keputusan karier, yakni penilaian diri, pengumpulan informasi karier, pemilihan tujuan, perencanaan, dan pemecahan masalah. Aspek-aspek ini mirip dengan aspek pengambilan keputusan Splete dan Pietrofesa (1975), yaitu pemahaman akan proses pengambilan keputusan karier, penilaian diri, pengumpulan informasi karier, analisis potensi dan pilihan karier, dan eksekusi (memilih, merencanakan, dan bertindak). Tidak hanya itu, aspek tersebut juga mirip dengan aspek perencanaan karier Jaffe dan Scott (1991), yakni penilaian diri, pengumpulan informasi karier (eksplorasi peluang), perencaaan (termasuk di dalamnya penetapan tujuan dan menyusun rencana karier), implementasi (melakukan rencana tindakan), dan evaluasi hasil. Apabila ketiga teori ini (Taylor \& Betz, Splete \& Pietrofesa, serta Jaffe \& Scott) dibandingkan, maka ditemukan kemiripan, yakni pada aspek penilaian diri, pengumpulan informasi karier, pemilihan atau penetapan tujuan, dan perencanaan. Oleh karenanya, penulis memandang bahwa penggunaan teori efikasi diri Bandura akan lebih mampu mengungkap efikasi diri secara mendalam dimana pengambilan keputusan karier merupakan situasi spesifik dari efikasi diri.

Menurut Wibisono (2016), 95\% pengukuran dalam kajian psikologi masih dikembangkan berdasarkan pendekatan teori tes klasik (classical test theory/CTT). Di satu sisi, sejauh ini sebagian besar alat ukur psikologi masih dikembangkan dengan CTT, namun di sisi lain, telah banyak kritik yang ditujukan pada pendekatan ini. Salah satunya kritik dari Alagumalai, Curtis, \& Hungi (2005) yakni, daya diskriminasi dan taraf kesukaran aitem tergantung pada sampel, skor tampak dan skor murni tergantung pada tes terutama pada tingkat kesulitan tes, dan adanya asumsi eror pengukuran yang setara untuk semua responden. Mitchel (2002) pun menyebutkan bahwa jenis data yang didapat melalui teknik pengukuran yang menanyakan opini atau sikap, adalah nominal dan ordinal sehingga alat analisis yang bisa digunakan pun terbatas. Pendekatan teori tes klasik inipun kemudian diperbaiki dengan munculnya teori respon butir (item response theory/IRT). Salah satu model pendekatan dalam IRT adalah model Rasch.

Menurut Sumintono \& Widhiarso (2014) keunggulan pemodelan Rasch dibanding metode lainnya, khususnya teori tes klasik, yaitu kemampuan melakukan prediksi terhadap data hilang 
(missing data), berdasarkan pola respon individu. Keunggulan ini menjadikan hasil analisis statistik model Rasch lebih akurat dalam penelitian yang dilakukan, dan yang lebih penting lagi, pemodelan Rasch mampu menghasilkan nilai pengukuran eror standar untuk instrumen yang digunakan yang dapat meningkatkan ketepatan perhitungan. Kalibrasi dilakukan dalam pemodelan Rasch secara sekaligus dalam tiga hal, yaitu skala pengukuran, responden (person), dan aitem (item). Suatu instrumen yang tidak dikalibrasi maka mempunyai kemungkinan menghasilkan data yang tidak valid dan bisa menyebabkan kegiatan riset yang dilakukan mengalami kegagalan. Bond dan Fox (2007) menyampaikan bahwa penggunaan model Rasch dalam validasi instrumen akan menghasilkan informasi yang lebih holistik tentang instrumen dan lebih memenuhi definisi pengukuran. Oleh karenanya, penelitian ini pun menggunakan pemodelan Rasch dalam analisis datanya. Untuk memperjelas hasil analisis model Rasch dalam penelitian ini, dilakukan pula pengujian reliabilitasnya menggunakan pendekatan teori tes klasik. Hal ini dilakukan untuk membandingkan dan memperjelas hasil analisis model Rasch terhadap alat ukur efikasi diri dalam pengambilan keputusan karier siswa SMA.

Tujuan dari penelitian ini adalah untuk mengembangkan skala efikasi diri dalam pengambilan keputusan karier menggunakan model Rasch. Hasil dari penelitian adalah alat ukur yang memiliki kualitas yang baik sehingga dapat digunakan untuk memperoleh informasi yang akurat tentang efikasi diri dalam pengambilan keputusan karier para siswa. Hal ini sangat berguna bagi siswa itu sendiri sebagai bentuk evaluasi dan reflek- si diri, serta Psikolog, terutama Psikolog Sekolah, dan juga guru Bimbingan dan Konseling (BK) dalam melakukan pendampingan karier bagi siswa.

\section{Metode}

\section{Partisipan Penelitian}

Partisipan dari penelitian ini adalah siswa kelas XI SMA yang berasal dari tiga sekolah di wilayah Yogyakarta. Total partisipan berjumlah 144 orang, berusia 16-17 tahun. Partisipan terdiri dari 94 siswa jurusan Ilmu Pengetahuan Alam (IPA) dan 50 siswa jurusan Ilmu Pengetahuan Sosial (IPS). Semua partisipan berpartisipasi secara sukarela dalam pengisian instrumen.

\section{Tahapan Penelitian}

Terdapat beberapa tahapan dalam penelitian pengembangan alat ukur ini, yakni: pertama, identifikasi tujuan ukur (penetapan konstrak teoritik). Konstrak yang diungkap adalah efikasi diri dalam pengambilan keputusan karier. Efikasi diri dalam pengambilan keputusan karier adalah keyakinan individu akan kemampuannya untuk melakukan tugas-tugas terkait dengan membuat keputusan karier secara tepat. Karier yang dimaksud adalah studi lanjut ke perguruan tinggi (pemilihan program studi). Kedua, merumuskan aspek keperilakuan dan indikator keperilakuan yang dituangkan dalam blueprint. Skala efikasi diri dalam pengambilan keputusan karier ini disusun berdasarkan aspek atau dimensi efikasi diri yang dikemukakan Bandura (1997), yakni tingkat kesulitan, rentang keluasan bidang, dan tingkat kekuatan. Blueprint Skala Efikasi Diri dalam Pengambilan Keputusan Karier tersaji dalam tabel 1 berikut ini. 
Tabel 1.

Blueprint Skala Efikasi Diri dalam Pengambilan Keputusan Karier

\begin{tabular}{|c|c|c|c|c|}
\hline Aspek & Indikator & Contoh Aitem & Frekuensi & Bobot \\
\hline \multirow[t]{2}{*}{$\begin{array}{l}\text { Tingkat } \\
\text { kesulitan }\end{array}$} & $\begin{array}{l}\text { a. Keyakinan dalam } \\
\text { menghadapi tugas } \\
\text { yang sulit }\end{array}$ & $\begin{array}{l}\text { Saya yakin mampu mengatasi } \\
\text { kesulitan yang saya alami saat } \\
\text { proses pengambilan keputusan } \\
\text { karier. }\end{array}$ & 6 & $33,33 \%$ \\
\hline & $\begin{array}{l}\text { b. Keyakinan dalam } \\
\text { merencanakan tugas } \\
\text { terkait pengambilan } \\
\text { keputusan karier }\end{array}$ & $\begin{array}{l}\text { Saya yakin dapat merencanakan } \\
\text { langkah-langkah guna } \\
\text { mengambil keputusan karier } \\
\text { yang tepat. }\end{array}$ & 6 & \\
\hline \multirow[t]{2}{*}{$\begin{array}{l}\text { Rentang } \\
\text { keluasan } \\
\text { bidang }\end{array}$} & $\begin{array}{l}\text { a. Keyakinan dalam } \\
\text { menghadapi berbagai } \\
\text { situasi dalam proses } \\
\text { pengambilan } \\
\text { keputusan karier }\end{array}$ & $\begin{array}{l}\text { - Saya yakin mampu mengambil } \\
\text { keputusan karier yang terbaik } \\
\text { untuk saya meskipun teman- } \\
\text { teman meragukan kemampuan } \\
\text { saya. }\end{array}$ & 6 & $33,33 \%$ \\
\hline & $\begin{array}{l}\text { b. Keyakinan untuk } \\
\text { melakukan suatu tugas } \\
\text { yang belum pernah } \\
\text { dikerjakan }\end{array}$ & $\begin{array}{l}\text { Membuat keputusan program } \\
\text { studi adalah hal baru bagi saya, } \\
\text { namun saya yakin mampu } \\
\text { memilih dengan tepat. }\end{array}$ & 6 & \\
\hline \multirow[t]{2}{*}{$\begin{array}{l}\text { Tingkat } \\
\text { kekuatan }\end{array}$} & $\begin{array}{l}\text { a. Bertahan lebih lama } \\
\text { saat mengalami } \\
\text { kesulitan }\end{array}$ & $\begin{array}{l}\text { Saat ada pandangan negatif dari } \\
\text { teman-teman tentang pilihan } \\
\text { program studi saya, saya yakin } \\
\text { mampu bertahan dengan pilihan } \\
\text { saya. }\end{array}$ & 6 & $33,33 \%$ \\
\hline & $\begin{array}{l}\text { b. Keuletan dalam } \\
\text { berusaha dan } \\
\text { menghadapi tantangan }\end{array}$ & $\begin{array}{l}\text { - Saya yakin mampu mencari } \\
\text { berbagai solusi saat ada } \\
\text { kesulitan dalam membuat } \\
\text { keputusan karier. }\end{array}$ & 6 & \\
\hline
\end{tabular}

Metode penskalaan yang digunakan dalam skala ini adalah metode summated ratings (Likert) dengan lima pilihan respon, yakni SS (Sangat Sesuai), S (Sesuai), CS (Cukup Sesuai), TS (Tidak Sesuai), dan STS (Sangat Tidak Sesuai). Penulis membuat 36 aitem sesuai dengan blueprint yang telah dibuat sebelumnya. Bentuk aitem adalah pernyataan dengan lima pilihan respon.

Reviu aitem, dilakukan baik dari sisi bahasa maupun isi (professional judgement). Reviu aitem ini bertujuan untuk melihat kesesuaian aitem yang telah ditulis dengan aspek yang diungkap serta kesesuaian bahasa yang digunakan. Proses ini dilakukan untuk agar skala yang dibuat memiliki validitas isi yang baik. Proses reviu aitem dilakukan oleh tiga psikolog yang telah berpengalaman melakukan pendampingan karier pada siswa SMA. Hasilnya, keseluruhan aitem dipandang telah sesuai dengan tujuan pengukuran oleh para penilai, namun ada beberapa aitem yang perlu sedikit direvisi agar lebih mudah dipahami oleh responden. Dari proses ini, penulis melakukan beberapa perbaikan redaksi sesuai saran dari penilai. Skala yang telah disusun diuji coba pada 144 siswa SMA kelas XI untuk direspon. 
Analisis data dilakukan dengan menggunakan pendekatan model Rasch melalui program Winsteps. Dalam pendekatan model Rasch, selain memperhatikan aitem juga memperhatikan aspek responden dan menghitung besaran korelasinya. Hasil analisis yang ditampilkan adalah rangkuman statistik, indeks ketepatan aitem, indeks ketepatan responden, skalogram, unidimensionalitas, peta aitemresponden, dan analisis peringkat (rating scale). Selanjutnya, untuk memperjelas hasil analisis data dari pendekatan model Rasch ini, dilakukan pula analisis menggunakan pendekatan teori tes klasik. Dalam pendekatan teori tes klasik, pengujian reliabilitasnya menggunakan formula alpha Cronbach. Pada tahap kompilasi final, dilakukan finalisasi skala berdasarkan hasil analisis yang telah dilakukan sebelumnya.

\section{Hasil}

Berdasarkan hasil analisis menggunakan model Rasch didapatkan berbagai informasi, baik dari segi aitem maupun responden yang menjadi partisipan uji coba skala (person). Dalam penelitian ini, analisis data dilakukan beberapa kali sampai didapatkan sejumlah aitem yang memenuhi indeks ketepatan butir-model. Tahapan analisis terangkum dalam Tabel 2 berikut.

Pada analisis tahap pertama, 63 responden teridentifikasi sebagai outliers atau kurang tepat dengan model. Menurut Boone, Staver, \& Yale (2014), parameter yang digunakan untuk mengetahui ketepatan atau kesesuaian responden antara lain: pertama, nilai outfit mean square (MNSQ) yang diterima: 0,5 $<$ MNSQ $<1,5$. Kedua, nilai outfit Z-standard (ZSTD) yang diterima: $-2,0<$ ZSTD $<+2,0$. Ketiga, nilai

Tabel 2.

Rangkuman Tahapan Analisis

\begin{tabular}{|c|c|c|c|c|}
\hline Tahapan & $\begin{array}{c}\text { Jumlah Responden } \\
\text { yang Dianalisis }\end{array}$ & $\begin{array}{l}\text { Jumlah Aitem } \\
\text { yang Dianalisis }\end{array}$ & Hasil & Tindakan \\
\hline $\mathrm{I}$ & 144 & 36 & $\begin{array}{l}63 \text { responden } \\
\text { teridentifikasi sebagai } \\
\text { outliers atau kurang } \\
\text { tepat dengan model }\end{array}$ & $\begin{array}{l}\text { Mengeliminasi } \\
\text { responden yang } \\
\text { teridentifikasi sebagai } \\
\text { outliers atau kurang } \\
\text { tepat dengan model }\end{array}$ \\
\hline II & 81 & 36 & $\begin{array}{l}13 \text { aitem kurang tepat } \\
\text { dengan model }\end{array}$ & $\begin{array}{l}\text { Mengeliminasi aitem } \\
\text { yang kurang tepat } \\
\text { dengan model }\end{array}$ \\
\hline III & 81 & 23 & $\begin{array}{l}2 \text { aitem kurang tepat } \\
\text { dengan model }\end{array}$ & $\begin{array}{l}\text { Mengeliminasi aitem } \\
\text { yang kurang tepat } \\
\text { dengan model }\end{array}$ \\
\hline IV & 81 & 21 & $\begin{array}{l}1 \text { aitem kurang tepat } \\
\text { dengan model }\end{array}$ & $\begin{array}{l}\text { Mengeliminasi aitem } \\
\text { yang kurang tepat } \\
\text { dengan model }\end{array}$ \\
\hline V & 81 & 20 & $\begin{array}{l}\text { Tidak ada lagi aitem } \\
\text { yang kurang tepat } \\
\text { dengan model }\end{array}$ & - \\
\hline
\end{tabular}


point measure correlation (Pt Mean Corr) diterima: 0,4 $<\mathrm{Pt}$ Measure Corr $<0,85$. Nilai yang di luar batas kriteria menunjukkan pola respon yang perlu diidentifikasi lebih jauh. Setelah dicermati dari skalogram diketahui bahwa 63 orang ini memiliki pola respon inkonsisten dan tidak wajar. Untuk lebih jelasnya dapat dilihat dari Tabel 3 berikut.

Tabel 3 di bawah menunjukkan bahwa ada sejumlah responden yang memiliki pola respon yang unik. Salah satunya responden 136. Pada aitem G21, ia menjawab sangat tidak sesuai, padahal untuk aitem-aitem selanjutnya yang memiliki tingkat kesukaran lebih tinggi (lebih susah untuk disetujui) dia justru menjawab sangat sesuai. Hal ini mengindikasikan bahwa responden 136 kurang sungguh-sungguh dalam merespon. Responden 016 juga menunjukkan keunikan respon, yakni ia menjawab sangat tidak sesuai pada aitem 35, padahal untuk aitem-aitem selanjutnya yang tingkat kesukarannya lebih tinggi, ia justru menjawab sangat sesuai. Begitu pula dengan responden 111 dan yang lainnya. Selanjutnya, semua responden ini dieliminasi dari data sehingga total responden menjadi 81 orang.
Pada tahap kedua hingga kelima, dilakukan analisis untuk mengetahui aitem yang tidak sesuai atau tidak tepat dengan model. Kriteria yang digunakan untuk memeriksa kesesuaian aitem sama halnya dengan yang kriteria ketepatan responden, yakni nilai outfit mean square, outfit z-standard, dan point measure correlation (Boone, Staver, \& Yale, 2014). Aitem-aitem yang kurang tepat dengan model kemudian dieliminasi atau dikeluarkan dari proses analisis. Analisis berhenti saat tidak ada lagi aitem yang terindikasi memiliki ketepatan model yang rendah (misfit). Pada akhirnya, pada tahap analisis kelima, tidak ada lagi aitem yang teridentifikasi kurang tepat dengan model sehingga total aitem yang memenuhi indeks ketepatan butir-model berjumlah 20 aitem. Hasil analisis akhir dari skala efikasi diri dalam pengambilan keputusan karier yang berisi 20 aitem dengan jumlah responden 81 orang tersaji dalam Tabel 4 .

Secara keseluruhan, hasil analisis terhadap aitem dan responden menunjukkan bahwa tidak ada aitem yang terlewatkan untuk dijawab oleh responden atau semua responden mengisi keseluruhan aitem secara lengkap. Hal ini ditunjukkan dari angka 81 (ada 81 responden) dan angka 20 (ada 20 aitem) yang tertera pada

Tabel 3.

Pola Jawaban Responden

\begin{tabular}{cc}
\hline Nomor Responden & Jawaban Responden* \\
\hline 030 & 555555555555555555555555555554555355555 \\
016 & 55555555555555555555555555515555555555 \\
106 & 555555555555555555555554555555454545 \\
136 & 5551555555555555555555555555555555555 \\
111 & 5551551555555555555555555555455555555 \\
033 & 5555555555454553555545555445555553554 \\
\hline Keterangan : \\
* ditulis sesuai urutan aitem (G3, S18, G27, G21, G34, S23, L1, L13, L14, S24, S30, \\
G4, L25, L8, S17, S5, L32, S12, S7, L31, S11, G33, L20, S36, L26, S35, G10, G9, \\
S6, S29, G15, G28, L19, G16, G22, L2)
\end{tabular}


Tabel 4.

Rangkuman Hasil Analisis Akhir

\begin{tabular}{llc}
\hline & \multicolumn{1}{c}{ Output } & Hasil \\
\hline \multirow{4}{*}{ Aitem } & Reliabilitas aitem & 0,91 \\
& Indeks separasi & 3,15 \\
& Pemisahan strata (H) & 4,6 \\
& Nilai logit tertinggi & 1,21 logit (Aitem L2) \\
& Nilai logit terendah & $-0,92$ logit (Aitem S18) \\
Responden & Nilai rata-rata & 1,09 logit \\
& Reliabilitas responden & 0,91 \\
& Indeks separasi & 3,20 \\
& Pemisahan strata (H) & 4,53 \\
& Nilai logit tertinggi & 5,46 logit (Nomor 106) \\
& Nilai logit terendah & $-1,02$ logit (Nomor 086) \\
& alpha Cronbach & 0,91 \\
& Raw variance explained by measures & $42,9 \%$ \\
& Unexplained variance in 1st contrast & $13,5 \%$ \\
& Unexplained variance in 2nd contrast & $6,8 \%$ \\
\hline
\end{tabular}

hasil item measure dan person measure. Nilai reliabilitas aitem sebesar 0,91 menunjukkan bahwa kualitas aitem dalam instrumen ini tergolong tinggi. Dengan kata lain, keduapuluh yang teridentifikasi memiliki ketepatan dengan model tersebut memang merupakan aitem-aitem yang berkualitas. Selanjutnya, nilai reliabilitas responden sebesar 0,91 menunjukkan bahwa konsistensi jawaban dari responden tergolong tinggi. Dengan kata lain, responden menjawab keseluruhan aitem dengan sungguh-sungguh (tidak asal-asalan). Untuk memperjelas gambaran hasil yang diperoleh, berikut ini ditampilkan informasi sebaran aitem berdasarkan tingkat persetujuan responden.

Berdasarkan Gambar 1 diketahui bahwa aitem yang paling susah disetujui oleh responden adalah aitem L2, ditunjukkan dari nilai 1,21 logit yang merupakan nilai tertinggi di antara aitemaitem lain. Sementara itu, aitem yang paling mudah disetujui oleh responden adalah aitem S18, ditunjukkan dari nilai 0,92 logit yang merupakan nilai paling rendah. Dengan kata lain, aitem L2 memiliki timgkat kesulitan tertinggi $(1,21$ logit) dan aitem S18 memiliki tingkat kesulitan terendah $(-0,92$ logit).

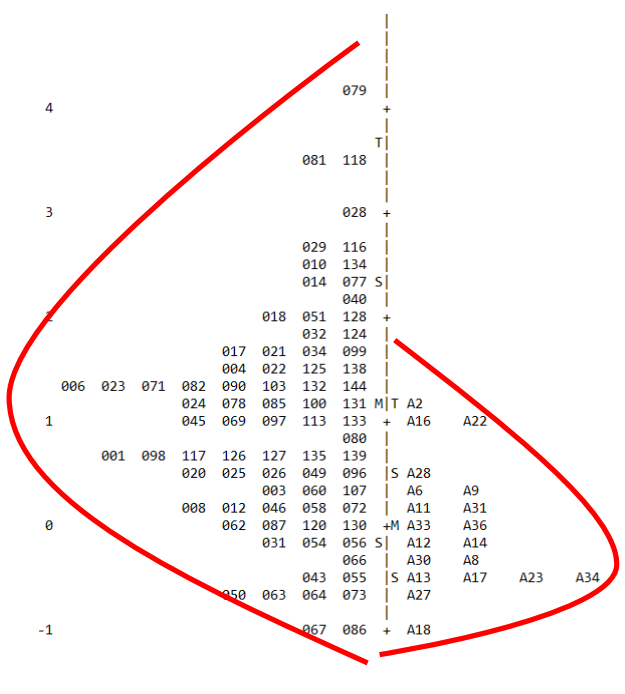

Gambar 1. Peta Aitem-Responden

Besarnya nilai rata-rata responden dalam skala efikasi diri dalam pengambilan keputusan karier ini sebesar 1,09 logit. Responden yang mempunyai level efikasi diri dalam pengambilan keputusan 
karier tertinggi adalah responden nomor 106, ditunjukkan dari nilai 5,46 logit yang merupakan nilai logit tertinggi. Sebaliknya, responden yang mempunyai level efikasi diri dalam pengambilan keputusan karier terendah adalah responden nomor 086, ditunjukkan dari nilai -1,02 logit yang merupakan nilai logit terendah.

Pengelompokkan responden dan aitem dapat diketahui dari indeks separasi. Indeks separasi responden yang diperoleh adalah 3,20 dan indeks separasi aitemnya adalah 3,15 . Artinya, terdapat 3 kelompok responden dan 3 kelompok aitem. Untuk melihat pengelompokkan secara lebih detil dapat digunakan persamaan pemisahan strata $\mathrm{H}=\{(4 \mathrm{x}$ indeks separasi +1$) / 3\}$. Hasilnya, untuk responden $\mathrm{H}=4,6$ (dibulatkan jadi 5). Hal ini menunjukkan bahwa responden dapat dibagi ke dalam lima kelompok. Sementara itu, untuk aitem $\mathrm{H}=4,53$ (dibulatkan jadi 5). Artinya, aitem-aitem yang digunakan dalam penelitian ini dapat dibagi ke dalam lima level berdasarkan tingkat kesulitannya untuk disetujui responden.

Nilai alpha Cronbach yang diperoleh dari hasil analisis instrumen adalah sebesar 0,91. Artinya, reliabilitas yang diperoleh alat ukur ini tergolong tinggi. Berikut ini ditampilkan fungsi informasi pengukuran.

Gambar 2 di bawah menunjukkan grafik fungsi informasi pengukuran. Dari gambar tersebut tampak bahwa pada level efikasi diri dalam pengambilan keputusan karier yang rendah, informasi yang diperoleh dari pengukuran juga cukup rendah. Begitu pula pada level efikasi diri dalam pengambilan keputusan karier yang tinggi. Pada level efikasi diri dalam pengambilan keputusan karier yang sedang, informasi yang diperoleh dari pengukuran sangat tinggi. Hal ini menunjukkan bahwa instrumen skala efikasi diri dalam pengambilan keputusan karier ini menghasilkan informasi yang optimal ketika diberikan pada individu dengan level efikasi diri dalam pengambilan keputusan karier sedang.

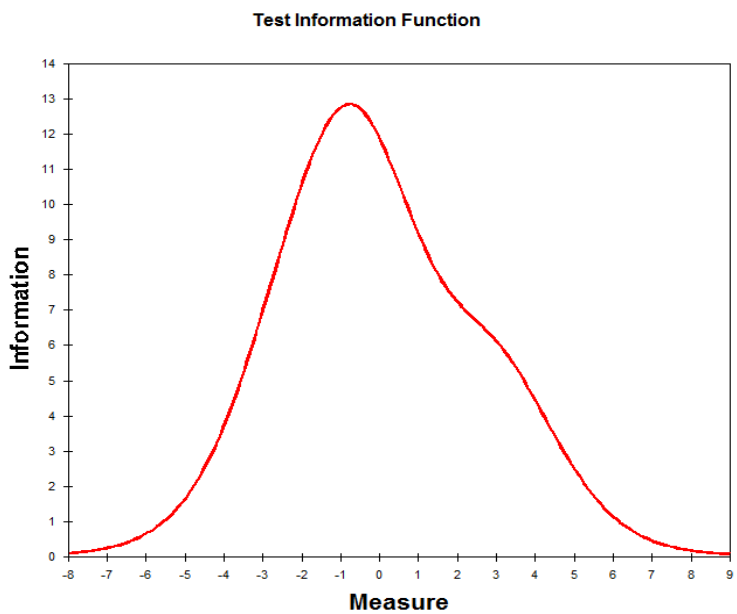

Gambar 2. Fungsi Informasi Pengukuran

Hasil penting lain yang perlu diketahui dalam pengembangan alat ukur psikologi adalah unidimensionalitas alat ukur. Hal ini berguna untuk mengetahui apakah instrumen yang dikembangkan mampu mengukur yang seharusnya diukur. Dalam konteks penelitian ini, konstrak efikasi diri dalam pengambilan keputusan karier. Dari Tabel 4 diketahui bahwa hasil pengukuran raw variance data adalah sebesar $42,9 \%$. Menurut Sumintono \& Widhiarso (2014), syarat minimal unidimensionalitas adalah $20 \%$, dan jika nilainya lebih dari 40\%, maka lebih baik lagi, serta varians yang tidak dapat dijelaskan oleh instrumen idealnya tidak melebihi 15\%. Berdasarkan penjelasan tersebut, maka hasil raw variance data sebesar $42,9 \%$ menunjukkan bahwa persyaratan unidimensionalitas minimal 20\% dapat terpenuhi dan bahkan tergolong baik karena lebih dari $40 \%$. Hasil analisis varians yang tidak dapat dijelaskan oleh instrumen sebesar 13,5\% juga memenuhi kriteria yakni, tidak melebihi $15 \%$. 
Setelah dilakukan analisis menggunakan model Rasch, diperoleh 20 aitem yang memiliki indeks ketepatan model sesuai kriteria. Keduapuluh aitem tersebut mewakili tiga aspek yang diungkap dalam skala efikasi diri pengambilan keputusan karier. Sebaran aitem dari tiap aspek setelah dianalisis menggunakan model Rasch tersaji dalam Tabel 5.

Berdasarkan Tabel 5 tampak bahwa ada beberapa aitem yang memiliki nilai logit yang sama. Meskipun demikian, aitem tersebut mengukur aspek yang berbeda sehingga aitem-aitem tersebut tetap dipertahankan dalam skala versi final. Dari Tabel 5 juga diketahui bahwa jumlah aitem per aspek berbeda, yang menunjukkan ketidaksesuaian dengan rancangan di blueprint awal. Sesuai desain analisis data maka selanjutnya dilakukan analisis rating scale yang bertujuan untuk memverifikasi apakah peringkat pilihan yang digunakan membingungkan responden atau tidak. Hasil analisisnya tersaji dalam Tabel 6.

Tabel 5.

Sebaran Aitem setelah Dianalisis

\begin{tabular}{|c|c|c|c|}
\hline Aspek & $\begin{array}{c}\text { Aitem yang Sesuai } \\
\text { Model }\end{array}$ & Frekuensi & Pernyataan (Contoh Aitem) \\
\hline $\begin{array}{c}\text { Tingkat } \\
\text { kesulitan }\end{array}$ & $\begin{array}{l}\text { L2 (1,21 logit) } \\
\text { L31 (0,10 logit) } \\
\text { L14 (-0,23 logit) } \\
\text { L8 (-0,40 logit) } \\
\text { L13 (-0,45 logit) }\end{array}$ & 5 & $\begin{array}{l}\text { - Saya ragu dapat membuat keputusan } \\
\text { program studi yang tepat untuk saya (Aitem } \\
\text { L31) } \\
\text { - Saya yakin dapat merencanakan langkah- } \\
\text { langkah guna mengambil keputusan karier } \\
\text { yang tepat } \\
\text { (Aitem L14) }\end{array}$ \\
\hline $\begin{array}{c}\text { Rentang } \\
\text { keluasan } \\
\text { bidang }\end{array}$ & $\begin{array}{l}\text { G16 }(1,00 \text { logit }) \\
\text { G22 }(0,93 \text { logit }) \\
\text { G28 }(0,54 \text { logit }) \\
\text { G9 }(0,30 \text { logit }) \\
\text { G33 }(0,04 \text { logit }) \\
\text { G34 (-0,43 logit }) \\
\text { G27 (-0,64 logit })\end{array}$ & 7 & $\begin{array}{l}\text { Sulit rasanya membuat keputusan program } \\
\text { studi karena saya tidak memiliki } \\
\text { pengalaman serupa sebelumnya (Aitem G16) } \\
\text { - Saya memang belum pernah membuat } \\
\text { keputusan karier sebelumnya, namun saya } \\
\text { yakin mampu melakukannya } \\
\text { (Aitem G34) }\end{array}$ \\
\hline $\begin{array}{c}\text { Tingkat } \\
\text { kekuatan }\end{array}$ & $\begin{array}{l}\text { S6 }(0,30 \text { logit }) \\
\text { S11 ( } 0,10 \text { logit }) \\
\text { S36 ( } 0,02 \text { logit }) \\
\text { S12 }(-0,23 \text { logit }) \\
\text { S30 }(-0,34 \text { logit }) \\
\text { S23 (0,43 logit) } \\
\text { S17 (-0,48 logit }) \\
\text { S18 (-0,92 logit })\end{array}$ & 8 & $\begin{array}{l}\text { - Saya ragu dapat mencari solusi terbaik } \\
\text { apabila terdapat hambatan dalam proses } \\
\text { pengambilan keputusan karier (Aitem S6) } \\
\text { - Saya ragu mampu mengerahkan segala daya } \\
\text { upaya untuk bisa menentukan pilihan progran } \\
\text { studi yang tepat untuk saya (Aitem S36) }\end{array}$ \\
\hline
\end{tabular}


Tabel 6.

Hasil Perhitungan Rating Scale

\begin{tabular}{cc}
\hline Label Kategori & $\begin{array}{c}\text { Observed Average } \\
\text { (Nilai rata-rata observasi) }\end{array}$ \\
\hline 1 & $-0,93$ \\
2 & $-0,28$ \\
3 & 0,48 \\
4 & 1,24 \\
5 & 2,88 \\
\hline
\end{tabular}

Hasil analisis menunjukkan bahwa rata-rata observasi dimulai dari logit $-0,93$ untuk pilihan skor 1 (sangat tidak sesuai), $-0,28$ untuk pilihan skor 2, dan meningkat hingga logit 2,88 untuk pilihan skor 5 . Dari sini terlihat dari pilihan 1 hingga pilihan 5 selalu terjadi kenaikan nilai logit. Adanya kenaikan secara monotonik ini menunjukkan bahwa pengukuran telah berlangsung dengan baik. Tidak adanya nilai yang setara pada kelima opsi ini menunjukkan bahwa responden dapat membedakan dengan jelas antar pilihan jawaban dari sangat tidak sesuai hingga sangat sesuai.

Dalam penelitian ini, dilakukan pula analisis menggunakan pendekatan teori tes klasik. Hasilnya, diketahui ada dua aitem yang gugur, yakni aitem nomor 1 dan 21. Kriteria pemilihan aitem menggunakan acuan dari Azwar (2012), yakni aitem yang baik adalah yang memiliki besaran indeks daya beda aitem (corrected item-total correlation) $\geq 0,30$. Dengan demikian, total aitem yang sahih berjumlah 34 aitem dengan indeks daya beda aitem berkisar dari 0,332 - 0,754. Koefisien reliabilitas dari skala ini dinyatakan dengan nilai alpha Cronbach sebesar 0,942.

\section{Diskusi}

Berdasarkan hasil analisis dengan pemodelan Rasch, diketahui bahwa skala efikasi diri dalam pengambilan keputusan karier siswa ini memberikan hasil yang konsisten dan terbukti mengungkap satu konstrak psikologis (unidimensi), yakni efikasi diri dalam pengambilan keputusan karier. Dari 36 aitem yang dianalisis terdapat 20 aitem yang sesuai model, dengan koefisien reliabilitas alpha 0,91. Nilai alpha ini merupakan ukuran reliabilitas yang dalam praktek pengukurannya berupa interaksi antara responden dan aitem secara keseluruhan. Hasil koefisien reliabilitas alpha sebesar 0,91 menunjukkan bahwa skala efikasi diri dalam pengambilan keputusan karier ini memiliki koefisien reliabilitas yang tinggi. Artinya, skala ini menghasilkan skor pengukuran yang konsisten dan dapat dipercaya. Koefisien reliabilitas aitem dan respondennya pun tergolong baik, yakni 0,91 dan 0,91 . Hal ini menunjukkan bahwa keduapuluh aitem ini merupakan aitem yang berkualitas dan kelompok respondennya pun menjawab dengan sungguhsungguh. Kedua hasil ini semakin memperkuat dan menegaskan bahwa skala efikasi diri dalam pengambilan keputusan karier ini memanglah alat ukur yang berkualitas karena tidak hanya hasil pengukurannya yang dapat dipercaya, namun juga keduapuluhnya merupakan aitem yang berkualitas.

Berdasarkan hasil analisis menggunakan model Rasch dan teori tes klasik, didapatkan nilai koefisien reliabilitas alat ukur yang sama-sama memuaskan yakni 0,91 dan 0,942 . Artinya, apabila dilihat dari segi reliabilitasnya, maka terlihat bahwa skala efikasi diri dalam pengambilan keputusan karier ini merupakan alat ukur yang berkualitas karena mampu memberikan hasil pengukuran yang konsisten. Meskipun ada sedikit perbedaan, namun hasil perhitungan menggunakan model Rasch dapat dikatakan lebih akurat karena data responden yang digunakan sudah 
bebas dari outliers. Sementara teori tes klasik tidak mempertimbangkan adanya outliers tersebut dan menganalisis data secara keseluruhan. Berbeda dengan teori tes klasik yang tidak memberikan informasi tentang kesesuaian responden dengan model, dalam Rasch model didapatkan informasi tentang indeks ketepatan responden dengan model. Dengan adanya informasi ini, diketahui adanya pola respon yang tidak konsisten dan tidak wajar pada sekelompok responden. Hal ini menunjukkan adanya indikasi menjawab asal-asalan pada sekelompok responden. Apabila menggunakan teori tes klasik, seluruh data responden diolah tanpa bisa diketahui secara akurat konsistensi dan kesungguhan responden dalam menjawab. Hal ini jelas menunjukkan bahwa Rasch model memang menghasilkan perhitungan yang lebih akurat karena tidak hanya menganalisis kesesuaian aitem namun juga responden.

Berdasarkan hasil analisis, ada 16 aitem yang teridentifikasi tidak tepat dengan model. Dengan kata lain, keenambelas aitem tersebut memiliki ketepatan model yang rendah sehingga perlu digugurkan. Pada aspek tingkat kesulitan, salah satu aitem yang gugur adalah aitem L1, yakni "Memilih program studi merupakan hal yang sulit bagi saya, namun saya yakin bisa melakukannya". Pada aspek rentang keluasan bidang, salah satu aitem yang gugur adalah aitem G3, yakni "Apabila orang tua meminta saya mendaftar pada program studi yang tidak saya minati, saya yakin dapat mendiskusikannya dengan orang tua saya". Pada aspek tingkat kekuatan, salah satu aitem yang gugur adalah S5, yakni "Adanya komentar negatif dari orangorang sekitar tentang prospek karier dari pilihan program studi yang saya minati, tidak menyurutkan langkah saya untuk tetap memilih program studi tersebut".
Berdasarkan hasil analisis terhadap keduapuluh aitem yang tepat model, diketahui bahwa aitem yang paling susah disetujui oleh responden adalah aitem L2 "Sulit rasanya bagi saya untuk menyusun rencana guna membuat keputusan karier yang tepat". Aitem ini memiliki nilai logit tertinggi di antara aitem-aitem lain, yakni 1,21 logit. Tampaknya, aitem ini menjadi aitem yang paling sulit disetujui oleh responden karena adanya unsur perencanaan. Tidak semua orang dapat dengan mudah membuat rencana karier. Selain itu, adanya kata "tepat" menjadi tambahan kesulitan dalam menyetujui aitem ini dengan mudah. Hal ini karena ketepatan pemilihan jurusan bisa menjadi problematika tersendiri. Seseorang dapat saja menyusun rencana karier, namun apakah itu sudah mendukung dirinya dalam mengambil keputusan karier yang tepat atau belum. Oleh karenanya, tidak mudah bagi responden untuk menyetujui aitem ini dengan mudah.

Aitem yang paling mudah disetujui oleh responden adalah aitem S18 "Saya yakin dapat melakukan berbagai upaya agar dapat menentukan pilihan program studi yang terbaik untuk saya". Aitem ini memiliki nilai logitnya paling rendah yakni -0,92. Tampaknya aitem ini mudah disetujui oleh responden karena tidak terlalu spesifik dalam menyebutkan upaya yang dilakukan sehingga para responden dapat memberikan pemaknaan yang bervariasi menurut pandangan pribadi. Artinya, upaya yang dipikirkan oleh si A ketika menjawab belum tentu sama dengan yang dipikirkan si B. Oleh karenanya, responden tidak mengalami kesulitan dalam menyetujui aitem ini karena setiap responden dapat memaknainya sesuai kondisi diri masing-masing.

Besarnya nilai rata-rata responden dalam skala efikasi diri dalam pengam- 
bilan keputusan karier ini sebesar 1,09 logit. Hasil ini menunjukkan kecenderungan responden yang lebih banyak menjawab sangat setuju pada pernyataan di berbagai item (untuk aitem unfavorable, skoringnya disesuaikan dulu). Responden nomor 106 memiliki nilai logit tertinggi, yakni 5,46 logit. Hal ini menunjukkan bahwa responden tersebut mempunyai level efikasi diri dalam pengambilan keputusan karier tertinggi dibanding lainnya. Sementara itu, responden nomor 086 memiliki nilai logit terendah yakni, -1,02. Hal ini menunjukkan bahwa responden tersebut mempunyai level efikasi diri dalam pengambilan keputusan karier terendah dibanding lainnya. Responden 086 ini lebih banyak menjawab atau memberikan respon ke arah tidak setuju.

Indeks separasi responden yang diperoleh adalah 3,20 dan indeks separasi aitem adalah 3,15. Menurut Sumintono \& Widhiarso (2014), makin besar nilai separasi maka kualitas instrumen dalam hal keseluruhan responden dan aitem makin bagus karena mampu mengidentifikasi kelompok responden dan aitem. Apabila dilihat lebih detil menggunakan persamaan pemisahan strata $(\mathrm{H})$, maka untuk responden $\mathrm{H}=4,6$ (dibulatkan jadi 5) dan untuk aitem $\mathrm{H}=4,53$ (dibulatkan jadi 5). Hasil ini menunjukkan bahwa responden dapat dibagi ke dalam lima kelompok besar, yaitu kelompok yang memiliki nilai efikasi diri dalam pengambilan keputusan karier sangat tinggi, tinggi, sedang, rendah, dan sangat rendah. Sementara aitem dapat dibagi ke dalam lima level berdasarkan tingkat kesulitannya untuk disetujui responden, yakni sangat mudah, mudah, sedang, sulit, dan dan sangat sulit. Hal ini dapat dimaknai bahwa aitem-aitem yang digunakan telah secara teliti mampu menilai jawaban responden, kaitannya dengan konstrak efikasi diri dalam pengambilan keputusan karier. Nilai indeks separasi, baik pada aitem dan responden tergolong cukup besar. Hal ini menunjukkan bahwa skala ini memiliki kualitas yang baik karena mampu mengidentifikasi kelompok responden dan aitem dengan cukup teliti.

Berdasarkan grafik fungsi informasi pengukuran, diketahui bahwa pada level efikasi diri dalam pengambilan keputusan karier yang sedang, informasi yang diperoleh dari pengukuran sangat tinggi. Sementara pada level efikasi diri dalam pengambilan keputusan karier yang rendah dan tinggi, informasi yang diperoleh dari pengukuran tergolong cukup rendah. Hal ini menunjukkan bahwa instrumen skala efikasi diri dalam pengambilan keputusan karier ini menghasilkan informasi yang optimal ketika diberikan pada individu dengan level efikasi diri dalam pengambilan keputusan karier sedang.

Keunggulan lain dari model Rasch adalah kemampuannya dalam memverifikasi rating atau peringkat pilihan yang digunakan apakah sudah jelas atau justru membingungkan responden. Hasil analisis rating scale menunjukkan bahwa rata-rata observasi dimulai dari logit $-0,93$ untuk pilihan skor 1 hingga logit 2,88 untuk pilihan skor 5. Dari sini terlihat dari pilihan 1 hingga pilihan 5 selalu terjadi kenaikan nilai logit. Adanya kenaikan secara monotonik ini menunjukkan bahwa pengukuran telah berlangsung yang baik. Responden tidak mengalami kebingungan dalam memastikan perbedaan antar pilihan respon jawaban. Dengan demikian, opsi pilihan pada skala efikasi diri dalam pengambilan keputusan karier ini sudah tepat digunakan.

Berdasarkan hasil analisis diketahui bahwa dari 20 aitem yang sesuai model terdapat beberapa aitem yang memiliki nilai logit yang sama. Meskipun demikian, 
aitem tersebut mengukur aspek yang berbeda sehingga aitem-aitem tersebut tetap dipertahankan (tidak dieliminasi). Temuan lain yang juga menarik adalah jumlah aitem untuk tiap asepk tidaklah berimbang. Hal tersebut menjadi catatan penting bagi penelitian ini bahwa bobot keterwakilan aitem di tiap aspek berbeda. Menurut Azwar (2012), kadangkala bobot tidaklah terlalu dipentingkan dalam penyusunan alat ukur, terutama untuk konstrak psikologi yang sederhana. Sayangnya tidak ada penjelasan lebih lanjut terkait konstrak sederhana ini sehingga tidak dapat dipastikan apakah efikasi diri dalam pengambilan keputusan karier merupakan konstrak sederhana atau tidak. Jika tidak, maka tentu saja pembobotan aspek ini menjadi hal yang krusial. Azwar (2012) juga menjelaskan bahwa apabila masing-masing aspek tidak mempunyai tujuan ukur dan peranan yang berbeda secara spesifik satu sama lain, maka perbedaan jumlah aitem atau bobot antar aspek tidaklah terlalu dipikirkan. Dengan berlandaskan dua penjelasan ini maka proporsionalitas jumlah aitem dalam tiap aspek merupakan hal yang penting, terutama jika terdapat tujuan khusus yang membedakan antar aspek. Namun, tidak ada larangan juga untuk memperhatikan proporsionalitas bobot atau jumlah aitem pada tiap aspek. Hal ini mengacu pada penjelasan Azwar (2012) bahwa aspek keperilakuan dari suatu atribut psikologi yang diukur belum tentu memiliki signifikansi kontribusi yang sama. Suatu aspek yang lebih berperan dan memiliki konstribusi lebih besar terhadap atribut haruslah mendapat bobot yang lebih besar pula.

\section{Kesimpulan}

Berdasarkan hasil analisis dengan pemodelan Rasch, skala efikasi diri dalam pengambilan keputusan karier siswa ini terbukti memberikan hasil yang konsisten dan terbukti mengungkap satu konstrak psikologis (unidimensi), yakni efikasi diri dalam pengambilan keputusan karier. Terdapat 20 aitem yang sesuai model, dengan koefisien reliabilitas instrumen 0,91 koefisien reliabilitas aitem 0,91 , dan koefisien relibilitas responden 0,91 . Artinya, skala ini menghasilkan skor pengukuran yang konsisten dan dapat dipercaya dengan kualitas aitem yang baik. Kelima alternatif jawaban (sangat tidak sesuai, tidak sesuai, cukup sesuai, sesuai, dan sangat sesuai) yang tersediapun sudah tepat digunakan karena responden tidak mengalami kebingungan dalam memastikan perbedaan antar pilihan respon jawaban. Secara keseluruhan dari hasil analisis, dapat disimpulkan bahwa skala efikasi diri dalam pengambilan keputusan karier ini terbukti memiliki properti psikometris yang baik sehingga dapat digunakan untuk instrumen dalam asesmen maupun penelitian.

\section{Saran}

Hasil analisis menunjukkan bahwa setiap aspek dalam skala efikasi diri dalam pengambilan keputusan karier ini diwakili oleh sejumlah aitem yang berbeda jumlahnya. Aspek tingkat kesulitan diungkap oleh 5 aitem, aspek rentang keluasan bidang 7 aitem, dan aspek tingkat kekuatan 8 aitem. Untuk penelitian selanjutnya, disarankan untuk mempertimbangkan proporsionalitas bobot atau jumlah aitem dari setiap aspek. Dalam penelitian ini juga belum dilakukan analisis deteksi bias pengukuran. Oleh karenanya, bagi peneliti selanjutnya dapat melakukan analisis deteksi bias pengukuran untuk mengevaluasi apakah aitem yang disusun lebih memihak atau menguntungkan responden dengan karakteristik tertentu atau tidak. 


\section{Kepustakaan}

Alagumalai, S., Curtis, D.D., \& Hungi, N. (2005). Applied rasch measurement: book of exemplars. Dordrecth: Springer.

Argyropoulou, E.P., SidiropoulouDimakakou, D., \& Besevegis, E.G. (2007). Generalized self-efficacy, coping, career indecision, and vocational choice of senior high school students in greece: implication for career guidance practitioners. Journal of Career Development, 33(4), 316-337. https://doi.org/10.1177/08948453073004 12

Azwar, S. (2012). Penyusunan skala psikologi edisi 2. Yogyakarta : Pustaka Pelajar.

Bandura, A. (1986). Social foundations of thought and action : A social cognitive theory. New Jersey : Prentice-Hall.

Bandura, A. (1997). Self efficacy : the exercise of control. New York : Freeman.

Betz, N.E., Klein, K., \& Taylor, K.M. (1996). Evaluation of a short form of the career decision making self-efficacy scale. Journal of Career Assessment, 4(1), 47-57. https://doi.org/10.1177/1069072 79600400103

Betz, N.E., \& Luzzo, D. (1996). Career assessment and the career decision self-efficacy scale. Journal of Career Assessment, 4(4), 413-428.

https://doi.org/10.1177/10690727960040 0405

Bond, T.G., \& Fox, C. (2007). Applying the rasch model. Fundamental measurement in the human sciences. New Jersey : Lawrence Erlbaum.

Boone, W.J., Staver, J.R. and Yale, M.S. (2014). Rasch Analysis in the Human Sciences. Dordrecht: Springer.

Creed, P., Patton, W., \& Prideaux, L.A. (2006). Causal relationship between career indecision and career decision making self-efficacy. Journal of Career Development, 33(1), 47-65.

https://doi.org/10.1177/08948453062895 35

Flores, L. Y., Ojeda, L., Huang, Y., Gee, D., \& Lee, S. (2006). The relation of acculturation, problem-solving appraisal, and career decision-making self-efficacy to mexican american high school students' educational goals. Journal of Counseling Psychology, 53(2), 260-266. http://dx.doi.org/10.1037/0022 $-0167.53 .2 .260$

Germeijs, V., \& Verschueren, K. (2006). High school student's career decisionmaking process : development and validation of the study choice task inventory. Journal of Career Assessment, 14 (4), 449-471.

https://doi.org/10.1177/10690727062865 10

Hirschi, A., \& Lage, D. (2007). The relation of secondary students career choice readiness to a six-phase model of career decision-making. Journal of Career Development, 34(2), 164-191. https://doi.org/10.1177/08948453073074 73

Jaffe, D. T., \& Scott, C. D. (1991). Career Development for Empowerment in a Changing Work World. Dalam Kummerow, J. M. (Ed.). New Directions in Career Planning (hlm. 33-59). California: CPP Books.

Makransky, G. Rogers, M. E., \& Creed, P. E. (2015). Analysis of the construct validity and measurement invariance of the career decision self-efficacy scale: a rasch model approach. Journal of Career Assessment, 23(4), 645-660. http://dx.doi.org/10.1177/106907271455 3555

Miguel, J.P., Silva.J.T., \& Prieto, G. (2013). Career decision self-efficacy scale- 
short form : a rasch analysis of the portuguese version. Journal of Vocational Behavior, 82(2), 116-123. http://dx.doi.org/10.1016/j.jvb.2012.12. 001

Mitchel, J. (2002). Stevens's theory of scales of measurement and its place in modern psychology. Australian Journal of Psychology, 54(2), 99-104. http://dx.doi.org/10.1080/000495302100 01706563

Nam, S. K., Yang, E., Lee, S. M., Lee, S. H., \& Seol, H. (2010). A psychometric evaluation of the career decision selfefficacy scale with korean students: a rasch model approach. Journal of Career Development, 38(2), 147-166. http://dx.doi.org/10.1177/089484531037 1374

Pappas, T. S., Kounenou, K. (2011). Career decision making of greek post secondary vocational students: the impact of parents and career decision making self-efficacy. Procedia Social and Behavioral Sciences, 15, 3410- 3414. http://dx.doi.org/10.1016/j.sbspro.2011. 04.310

Safaria, T. (2016). Peran efikasi diri, pola asuh otoritatif, dan motivasi berprestasi terhadap kematangan karir. Jurnal Psikologi, 43(2), 154-166. http://dx.doi.org/10.22146/jpsi.10657
Sawitri, D. R. (2009). Pengaruh status identitas dan efikasi diri keputusan karir terhadap keraguan mengambil keputusan karir pada siswa SMA kelas 12. Naskah tidak dipublikasikan, Fakultas Psikologi, Universitas Indonesia, Depok.

Splete, H. , \& Pietrofesa, J.J. (1975). Career Development: Theory and Research. New York: Grune and Stratton.

Sumintono, B., \& Widhiarso, W. (2014). Aplikasi model rasch untuk penelitian ilmu-ilmu sosial. Jakarta: Tim Komunikata Publishing House.

Taylor, K. M., \& Betz, N. E. (1983) Applications of self-efficacy theory to the understanding and treatment of career indecision. Journal of Vocational Behavior, 22(1), 63-81. http://dx.doi.org/10.1016/0001-879 (83)90006-4

Wibisono, S. (2016). Aplikasi model rasch untuk validasi instrumen pengukuran fundamentalisme agama bagi responden muslim. Jurnal Pengukuran Psikologi dan Pendidikan Indonesia (JP3I), 5(1), 1-30.

Yulianto, U. (2012). Pengaruh konseling karir secara kelompok terhadap efikasi diri pengambilan keputusan studi lanjut pada siswa SMA. Naskah tidak dipublikasikan, Fakultas Psikologi, Universitas Gadjah Mada, Yogyakarta. 